\title{
Dormant Pruning and Fall Ethephon Application Influence Peach Pistil Hardiness
}

\author{
Edward F. Durner \\ Rutgers Fruit Research Center, New Jersey Agricultural Experiment Station, Cook College, Rutgers \\ University, 283 Route 539, Cream Ridge, NJ 08514
}

Additional index words. Prunus persica, bud hardiness, ethephon, exotherms, deep supercooling

\begin{abstract}
Flower bud hardiness of ethephon-treated (100 mg-liter in October), dormant pruned (in December) 'Redhaven' peach (Prunus persica L. Batsch.) trees was studied from December through March using exotherm analysis. In early December, buds not treated with ethephon were $0.5 \mathrm{C}$ hardier than ethephon-treated buds. From mid-December through March, ethephon-treated buds were 0.5 to $2.1 \mathrm{C}$ hardier than nontreated buds. When a main effect of pruning was detected, buds from pruned trees were 0.8 to $2.8 \mathrm{C}$ less hardy than buds from nonpruned trees. On several dates, a significant interaction on flower bud hardiness between ethephon treatment and pruning was detected. For trees not treated with ethephon, buds from pruned trees were 1.8 to $2.2 \mathrm{C}$ less hardy than those from nonpruned trees. Pruning did not affect hardiness of buds from ethephon-treated trees. Ethephon delayed bloom to the $75 \%$ fully open stage by 9 days. Pruning accelerated bloom to the $\mathbf{7 5 \%}$ fully open stage by 3 days compared to nonpruned trees. Flower bud dehardening under controlled conditions was also studied. As field chilling accumulated, flower buds dehardened more rapidly and to a greater extent when exposed to heat. Pruning accelerated and intensified dehardening. Ethephon reduced the pruning effect. The percentage of buds supercooling from any ethephon or pruning treatment did not change as chilling accumulated. In trees not treated with ethepbon, fewer buds supercooled as heat accumulated, and pruning intensified this effect. In pruned, ethephon-treated trees, fewer buds supercooled after exposure to heat. The number of buds supercooling in nonpruned trees did not change with heat accumulation. Flower bud rehardening after controlled dehardening was also evaluated. After dehardening in early February, there was no difference in the bud hardiness of pruned or nonpruned trees. Buds from ethepbon-treated trees were hardier than those from nontreated trees. With reacclimation, buds from pruned trees were not as hardy as those from nonpruned trees. The percentage of buds supercooling from ethephon-treated trees did not change with deacclimation or reacclimation treatments. After deacclimation in late February, buds from pruned trees were 2.2C less hardy than those from nonpruned trees. After reacclimation, buds from pruned, ethephon-treated trees rehardened 2.6C while buds from all other treatments remained at deacclimated hardiness levels or continued to deharden. Ethephon-treated pistils were shorter than nontreated pistils. Pistils from pruned trees were longer than those from nonpruned trees. Deacclimated pistils were longer than nondeacclimated pistils. Differences in hardiness among ethephon and pruning treatments were observed, but there was no relationship between pistil moisture and hardiness.
\end{abstract}

Peach floral primordia deep supercool during dormancy to temperatures below $-10 \mathrm{C}$ but above $-30 \mathrm{C}$ to avoid freezing injury (Quamme, 1978). After rest has been broken, the capacity to supercool decreases when buds are exposed to above-freezing temperatures. Just before bloom, buds do not deep supercool but will tolerate low temperatures (-3C) through extracellular freezing (Andrews et al., 1983). During and after bloom, pistils neither deep supercool nor tolerate freezing. Peach flower buds thus become increasingly susceptible to freezing injury as they develop. In the mid-Atlantic region of the eastern United States, freezes from late January through May often kill many pistils, resulting in economic losses. The growth regulator ethephon [(2chloroethyl) phosphonic acid] applied to peach at low rates (100 $\mathrm{mg} \cdot \mathrm{liter}^{-1}$ ) in the fall increases the chilling requirement of flower buds, reduces bud growth at warm temperatures (20 to 25C) after chilling (Dumer and Gianfagna, 1991a, 1991b), and increases the intrinsic hardiness of cherry (Proebsting and Mills, 1976) and peach (Dumer and Gianfagna, 1988; Proebsting and Mills, 1969) flower buds. The combination of increased chilling requirement and reduced growth delays bloom by as much as 16 days (Irving, 1987). Increasing cold hardiness and delaying bloom can increase

Received for publication 30 Nov. 1994. Accepted for publication 31 Mar. 1995. New Jersey Agricultural Experiment Station publication no. D-12111--94, supported by state and Hatch Act funds. I thank Francis X. Rooney for his technical assistance. Mention of trade names is for the convenience of the reader and does not constitute endorsement by the New Jersey Agricultural Experiment Station. The cost of publishing this paper was defrayed in part by the payment of page charges. Under postal regulations, this paper therefore must be hereby marked advertisement solely to indicate this fact. crop yields (Dumer and Gianfagna, 1988; Gianfagna, et al., 1989; Proebsting and Mills, 1976).

Durner and Gianfagna (1991a) have shown that ethephon enhances flower bud hardiness in three distinct ways: 1) it decreases the mean low temperature exotherm of pistils, 2) it increases the number of buds that supercool after exposure to deacclimating temperatures, and 3) it decreases the rate of deacclimation. Increased pistil sorbitol and sucrose content, together with reduced moisture, pistil size, and growth rates during deacclimation, may account for these phenomena (Durner, 1989; Durner and Gianfagna, 1991 b). Durner (1990) showed that pruning peach trees reduced flower bud rehardening during exposure to below-freezing temperatures after a late winter warm spell. A fall application of ethephon before pruning enhanced rehardening of pistils from pruned trees (Durner, 1990).

This study was initiated to investigate further the interactive effects of dormant pruning and ethephon on deep supercooling of peach pistils and to examine pistil responses to deacclimation and reacclimation under controlled conditions.

\section{Materials and Methods}

Field treatments. Ethephon (100 mg.liter $\left.{ }^{-1}\right)$ was applied to runoff on mature 'Redhaven' peach trees on 13 Oct. 1989 (+E). Regulaid $(0.1 \% \mathrm{v} / \mathrm{v})$ was added to assist spreading and was also used alone as a control (-E). Ethephon-treated and nontreated trees were pruned on 12 Dec. $1989(+\mathrm{P})$, or left unpruned (-P). Pruning consisted of moderate removal of shoots with thinning-out cuts and an occasional bench cut to maintain tree shape. The experi- 
mental units were single trees of similar vigor in a split-plot design. Main plots were ethephon treatment, replicated seven times in a randomized complete-block design, and subplots were pruning treatment.

Exotherm analysis. On 11 and 18 Dec. 1989 and 2, 16, 17, 19, 22, and 29 Jan., 9 and 21 Feb., and 13 Mar. 1990, flower buds were sampled for exotherm analysis from unbranched terminal shoots around the periphery of the canopy $2 \mathrm{~m}$ above the orchard floor. Exotherm analysis was performed as described by Durner (1990). At least 20 flower buds per ethephon-pruning treatment combination were sampled on each date. Low-temperature exotherms (LTEs) were subjected to an analysis of variance (ANOVA) using the Type III sums of squares from the General Linear Model procedure of PCSAS (SAS Institute, Gary, N.C.) and differences among means within date were determined via Fisher's protected LSD, $\alpha=0.05$.

Flower bud development. Flower bud development during bloom was monitored as described by Durner and Gianfagna (1990). Five twigs per tree were tagged, and the development of flower buds was monitored from late quiescence through full bloom. The percentages of total buds per twig in each of four developmental stages (quiescent, pink tip, balloon, and fully open) were calculated on 22 and 26 Mar. and 2, 6, and 12 Apr. 1990. The Julian dates for reaching 75\% pink, balloon, and fully open buds were calculated for individual trees. Data were subjected to an ANOVA and means were separated with Fisher's protected LSD, $\alpha=0.05$.

\section{Controlled dehardening studies}

Experiment I. On 17 Jan. 1990, fifty 30-cm terminal shoots were randomly sampled $2 \mathrm{~m}$ from the ground from the periphery of seven trees of each ethephon-pruning treatment combination. Twigs were wrapped in moist paper towels and placed in a controlled-environment chamber (Precision Scientific, Chicago) at $15 \pm 1 \mathrm{C}$. After 1 or 3 days of exposure, at least 30 flower buds per treatment combination were subject to exotherm analysis. Pistil lengths of five buds per treatment combination were measured before and after 3 days of deacclimation.

Experiment 2. On 22 Jan. 1990, buds were sampled as in Expt. 1 , subjected to deacclimation at either 10 or $21 \mathrm{C}$ for 2 days, and then subjected to exotherm analysis as previously described. Five bud samples from each ethephon-pruning treatment combination were dissected before and after deacclimation, and percentage moisture of pistils was determined gravimetrically.

Experiment 3. On 29 Jan. 1990, buds were sampled as in Expt. 1 and deacclimated at $21 \mathrm{C}$ for 2 days. Following deacclimation, buds were subjected to exotherm analysis, and pistil size and moisture content were determined as previously described.

Experiment 4. On 9 Feb. 1990, buds were sampled as in Expt. 1 and subjected to two treatments: 1 ) deacclimation at $21 \mathrm{C}$ for 2 days, or 2) deacclimation at $21 \mathrm{C}$ for 2 days plus reacclimation for 1 day at $-1 \mathrm{C}$. Following deacclimation-reacclimation treatment, buds were subjected to exotherm analysis.

Experiment 5. Experiment 4 was repeated on 21 Feb. 1990. In addition, following deacclimation-reacclimation treatment, pistil size and moisture content were determined as previously described.

Response surface regression analysis. LTE data from all five experiments were combined for a response surface regression analysis using the regression procedure of PCSAS (SAS Institute). Data from the rehardening portion of Expts. 4 and 5 were not included in the response surface analysis and were analyzed separately. Separate response surface regressions were performed for each pruning-ethephon treatment combination for a total of four analyses. The regression model used was a complete quadratic response surface model:

$Y=\beta_{0}+\beta_{1} X_{1}+\beta_{11} X_{1}^{2}+\beta_{2} X_{2}+\beta_{22} X_{2}^{2}+\beta_{12} X_{1} X_{2}+\beta_{1122} X_{1}^{2} X_{2}^{2}$ where $\mathrm{Y}=\mathrm{LTE}$ or the percentage of buds in each sample that supercooled, $X_{1}=$ chilling units (CUs) (Richardson et al, 1974) accumulated before sampling, and $\mathrm{X}_{2}=$ growing degree hours (GDH) base 4.5C accumulated before field sampling starting after the accumulation of $600 \mathrm{CUs}$ plus GDH (base 4.5C) accumulated during deacclimation after sampling from the field. Components were deleted from the model if their parameter estimate $(\beta)$ was not significant $(\alpha=0.05)$, if they increased the mean square error $\left(\sigma^{2}\right)$, or if their deletion did not decrease the $R^{2}$ of the model (Weisberg, 1985). Resulting equations were statistically compared using the method described by Weisberg (1985) to determine if deacclimation was significantly affected by ethephon or pruning treatment. Response surface equations were significantly different if A) final equations contained different components, or B) if parameter estimates of surfaces having the same components were statistically different. Response surface regressions and parameter tests were similarly performed on the percentages of buds tested that deep supercooled. Residual plots did not reveal a need for transformation of either LTEs or percentages supercooling.

Planned comparisons. Nontransformed percentages of buds supercooling and LTE data from Expts. 4 and 5 were subjected to an ANOVA. All data from Expts. 4 and 5 were used in the analysis; thus, some of the data were used in the response surface analysis and the planned comparisons. Planned comparisons (single degree of freedom $\mathrm{F}$ tests) were used to separate deacclimation effects within ethephon-pruning treatments, and Fisher's protected LSD was used to separate ethephon-pruning treatment effects within deacclimation treatments. Each experiment was analyzed separately.

Pistil size and moisture content. Pistil lengths from Expts. 1 and 3 were combined and moisture contents from Expts. 2 and 3 were combined and analyzed using an ANOVA, and means were separated with Fisher's protected LSD, $\alpha=0.05$. Since Expt. 5 included a reacclimation treatment, pistil size and moisture data were not combined with other experiments, but, rather, analyzed separately by ANOVA, and means were separated with Fisher's protected LSD, $\alpha=0.05$.

Table 1. Main effect mean low temperature exotherm (MLTE) values for 'Redhaven' flower buds on various dates as affected by October ethephon treatment or December pruning.

\begin{tabular}{lcc}
\hline \hline & \multicolumn{2}{c}{ MLTE $\left({ }^{\circ} \mathrm{C}\right)$} \\
\cline { 2 - 3 } Date & - & Treatment \\
\hline & Ethephon & \\
11 Dec. & $-21.3 \mathrm{~b}^{\mathrm{z}}$ & $-20.8 \mathrm{a}$ \\
18 Dec. & $-23.5 \mathrm{a}$ & $-24.5 \mathrm{~b}$ \\
19 Jan. & $-19.3 \mathrm{a}$ & $-20.3 \mathrm{~b}$ \\
22 Jan. & $-19.6 \mathrm{a}$ & $-20.5 \mathrm{~b}$ \\
29 Jan. & $-18.9 \mathrm{a}$ & $-19.4 \mathrm{~b}$ \\
21 Feb. & $-17.3 \mathrm{a}$ & $-18.3 \mathrm{~b}$ \\
13 Mar. & $-9.6 \mathrm{a}$ & $-11.7 \mathrm{~b}$ \\
& Pruning & $-19.4 \mathrm{a}$ \\
19 Jan. & $-20.2 \mathrm{~b}^{\mathrm{y}}$ & $-8.3 \mathrm{a}$; \\
13 Mar. & $-11.1 \mathrm{~b}$ & \\
\hline
\end{tabular}

${ }^{2}$ Mean separation within row by Fisher's protected LSD, $\alpha=0.05$. Values are means of at least 20 observations.

'Mean separation within row by Fisher's protected LSD, $\alpha=0.05$. Values are means of at least 40 observations. 


\section{Results}

Supercooling of field samples. A significant main effect of ethephon treatment on the mean LTE (MLTE) was detected on seven of the eleven sampling dates (Table 1), On 11 Dec., buds from $+\mathrm{E}$ trees were $0.5 \mathrm{C}$ less hardy than buds from-E trees. On the remaining six dates, buds from $+\mathrm{E}$ trees were significantly hardier than buds from -E trees. A pruning effect on MLTE was detected on 19 Jan. and 13 Mar. (Table 1). On both dates, buds from $+\mathrm{P}$ trees were less hardy than buds from -P trees.

A significant interaction between ethephon treatment and pruning was detected on 16 and 17 Jan. and 9 Feb. (Table 2). On 16 and 17 Jan., for-E trees, buds from $+\mathrm{P}$ trees were less hardy than those from-P trees. Hardiness of buds from $+\mathrm{E}$ trees was not affected by pruning on either date. On 9 Feb., buds from $+\mathrm{E}-\mathrm{P}$ trees were hardier than buds from any other treatment combination. No main effects or interactions were detected on the 2 Jan. sampling date (MLTE $=-20.8 \mathrm{C})$.

Over all dates, fewer buds on $+\mathrm{E}$ trees supercooled than-E buds (61.1\% and $76.5 \%$, respectively). The lower percentage of supercooling buds in the $+\mathrm{E}$ treatment is attributable to fewer live buds before freezing in the lab $(84.5 \%$ live $+\mathrm{E}$ buds compared to $96.0 \%$ live $-\mathrm{E}$ buds as determined by dissection). Pruning did not affect the percentage of buds that supercooled.

Bud development. Ethephon significantly delayed bud devel-

Table 2. Mean low temperature exotherm (MLTE) values for 'Redhaven' flower buds on various dates as affected by October ethephon application and December pruning.

\begin{tabular}{lcc}
\hline \hline & \multicolumn{2}{c}{ MLTE $\left({ }^{\circ} \mathrm{C}\right)$} \\
\cline { 2 - 3 } Ethephon & \multicolumn{2}{c}{ Pruning } \\
\cline { 2 - 3 } & 16 Jan. & + \\
\hline & $-19.3 \mathrm{~b}^{2}$ & $-17.1 \mathrm{a}$ \\
& $-20.8 \mathrm{a}$ & $-20.7 \mathrm{a}$ \\
+ & 17 Jan. & $-13.6 \mathrm{a}$ \\
+ & $-15.4 \mathrm{~b}$ & $-20.3 \mathrm{a}$ \\
\hline & $-18.2 \mathrm{a}$ & $-17.6 \mathrm{a}$ \\
+ & 9 Feb. & $-17.8 \mathrm{a}$ \\
\hline
\end{tabular}

Mean separation within row by Fisher's protected LSD, $\alpha=0.05$. Values are means of at least-20 observations. opment to the $75 \%$ pink stage by 11 days, to the $75 \%$ balloon stage by 6 days; and to the $75 \%$ fully open stage by 9 days. Buds on $+\mathrm{P}$ trees reached $75 \%$ pink and balloon 4 days earlier than $-\mathrm{P}$ trees. Buds from $+\mathrm{P}$ trees reached $75 \%$ fully open buds 3 days earlier than buds on $-\mathrm{P}$ trees.

\section{Response surface regression analysis}

The LTE response surface regression equations presented in Table 3 were significantly different from each other at $\alpha=0.05$. Flower bud hardiness was affected by ethephon and pruning treatment, and the response to chilling and GDH varied with ethephon and pruning treatment (Table 3, Fig. 1). In all cases, as more chilling accumulated, flower buds dehardened more rapidly and to a greater extent. The response to heat was consistently linear while the response to chilling was consistently quadratic, indicating that flower bud response to heat is constant while their response to chilling is continually changing. Buds from-E trees dehardened more rapidly and to a greater extent than buds from $+\mathrm{E}$ trees (Fig. 1 A vs. B). Pruning accelerated and intensified dehardening compared to no pruning (Fig. $1 \mathrm{C}$ vs. A). Buds from $+\mathrm{E}+\mathrm{P}$ trees dehardened to a greater extent and more rapidly than buds from + E-P trees, (Fig. D vs. B) but not as much as $-\mathrm{E}+\mathrm{P}$ trees (Fig. $1 \mathrm{D}$ vs. C).

The percentage of buds supercooling from any ethephon or pruning treatment was not affected by chilling accumulation (Table 3, Fig. 2). The percentage of buds supercooling from -E$\mathrm{P}$ trees, and $+\mathrm{E}+\mathrm{P}$ trees decreased as heat accumulated (Table 3; Fig. 2 A, C, and D). Pruning induced a more rapid decrease in the number of buds supercooling in response to GDH, especially as more heat accumulated, compared to no pruning (Fig. $2 \mathrm{C}$ vs. A). Fall treatment with ethephon reduced but did not negate the pruning effect on supercooling (Fig. $2 \mathrm{D}$ vs. C). The percentage of buds that supercooled on $+\mathrm{E}$ trees did not change with heat accumulation and was $62 \%$ (Fig. 2B).

\section{Planned comparisons}

Experiment 4 . Before deacclimation, buds from $+\mathrm{P}$ trees were less hardy than those from-P trees (MLTEs of -17.7 and $-18.3 \mathrm{C}$, respectively) and buds from $+\mathrm{E}$ trees were hardier than those from -E trees (MLTEs of -18.3 and $-17.7 \mathrm{C}$, respectively). After deacclimation, there was no difference in the hardiness of $+\mathrm{P}$ or $\mathrm{P}$ trees (MLTE of $-16.0 \mathrm{C}$ ); however, buds from $+\mathrm{E}$ trees remained hardier than those from $-\mathrm{E}$ trees (MLTEs of -17.0 and $-15.2 \mathrm{C}$, respectively). Upon reacclimation, buds from $+\mathrm{P}$ trees were not as hardy as those from -P trees (MLTEs of -18.2 and -18.9C,

Table 3. Regression equations, coefficients of determination $\left(R^{2}\right)$, model significance probabilities $(\mathrm{P}>\mathrm{F})$, and number of observations $(\mathrm{n})$ for lowtemperature exotherms (LTEs) of pistils and proportions of pistils tested that supercooled for 'Redhaven' peach treated in the fall with 100 ppm ethephon and pruned in December.

\begin{tabular}{|c|c|c|c|c|c|}
\hline Ethephon & Pruning & Equation $^{\mathrm{z}}$ & $R^{2}$ & $P>\mathrm{F}$ & $\mathbf{n}$ \\
\hline \multicolumn{6}{|c|}{$\operatorname{LTE}\left({ }^{\circ} \mathrm{C}\right)$} \\
\hline \multirow[t]{2}{*}{-} & - & $Y=-48.7+0.08328 * X_{1}-0.00783 * X_{2}+0.00001 * X_{1}^{*} X_{2}-0.00006 * X_{1}^{2}$ & 0.28 & 0.001 & 589 \\
\hline & + & $\mathrm{Y}=-35.5+0.05441 * \mathrm{X}_{1}-0.00799 * \mathrm{X}_{2}+0.00001 * \mathrm{X}_{1} * \mathrm{X}_{2}-0.00004 * \mathrm{X}_{1}^{2}$ & 0.31 & 0.001 & 609 \\
\hline \multirow[t]{2}{*}{+} & - & $\mathrm{Y}=-33.8+0.03639 * \mathrm{X}_{1}-0.00141 * \mathrm{X}_{2}+0.000004 * \mathrm{X}_{1} * \mathrm{X}_{2}-0.00002 * \mathrm{X}_{1}^{2}$ & 0.26 & 0.001 & 486 \\
\hline & + & $\begin{array}{c}\mathrm{Y}=-35.5+0.04300 * \mathrm{X}_{1}-0.00388 * \mathrm{X}_{2}+0.000007 * \mathrm{X}_{1}^{*} * \mathrm{X}_{2}-0.00003 * \mathrm{X}_{1}^{2} \\
\text { Proportion supercooling }\end{array}$ & 0.42 & 0.001 & 480 \\
\hline \multirow[t]{2}{*}{-} & - & $Y=90.7-0.01797 * X_{2}$ & 0.42 & 0.001 & 46 \\
\hline & + & $Y=85.7+0.01060 * X_{2}^{2}-0.0000109 * X_{2}^{2}$ & 0.44 & 0.001 & 45 \\
\hline \multirow[t]{2}{*}{+} & - & $\mathrm{Y}=62.1$ & 0.00 & 0.707 & 44 \\
\hline & + & $Y=71.88-0.01108 * X_{2}$ & 0.16 & 0.008 & 44 \\
\hline
\end{tabular}

${ }^{2} \mathrm{X}_{1}=$ chilling units in the field. $\mathrm{X}_{2}=$ growing degree hours base $4.5 \mathrm{C}$ in the field after the accumulation of 600 chilling units plus growing degree hours during controlled deacclimation. 

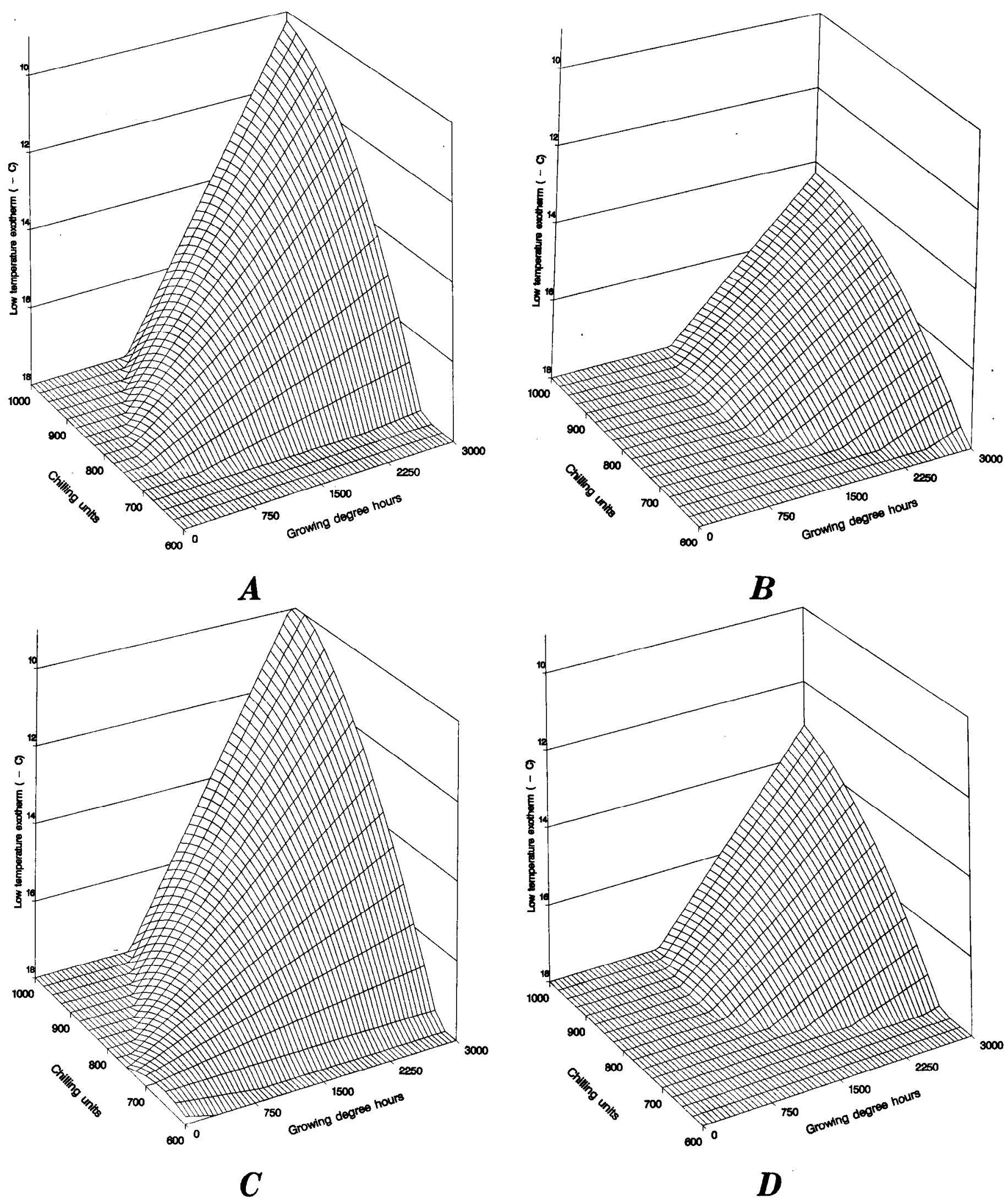

Fig. 1. Predicted mean low-temperature exotherm values derived from equations in Table 4 for 'Redhaven' peach flower buds receiving the following treatments : (A) -E-P; (B) +E-P; (C) -E+P; and (D) +E+P.

respectively). Buds from $+\mathrm{E}$ trees were hardier than those from $\mathrm{E}$ trees (MLTEs of -19.2 and $-17.8 \mathrm{C}$, respectively).

After exposure to $21 \mathrm{C}$, all buds dehardened except those from
$+\mathrm{E}+\mathrm{P}$ trees (Table 4), and all buds rehardened to predeacclimation levels with exposure to $-1 \mathrm{C}$. Buds from $+\mathrm{E}+\mathrm{P}$ trees were hardier after exposure to $-1 \mathrm{C}$ than before exposure. 

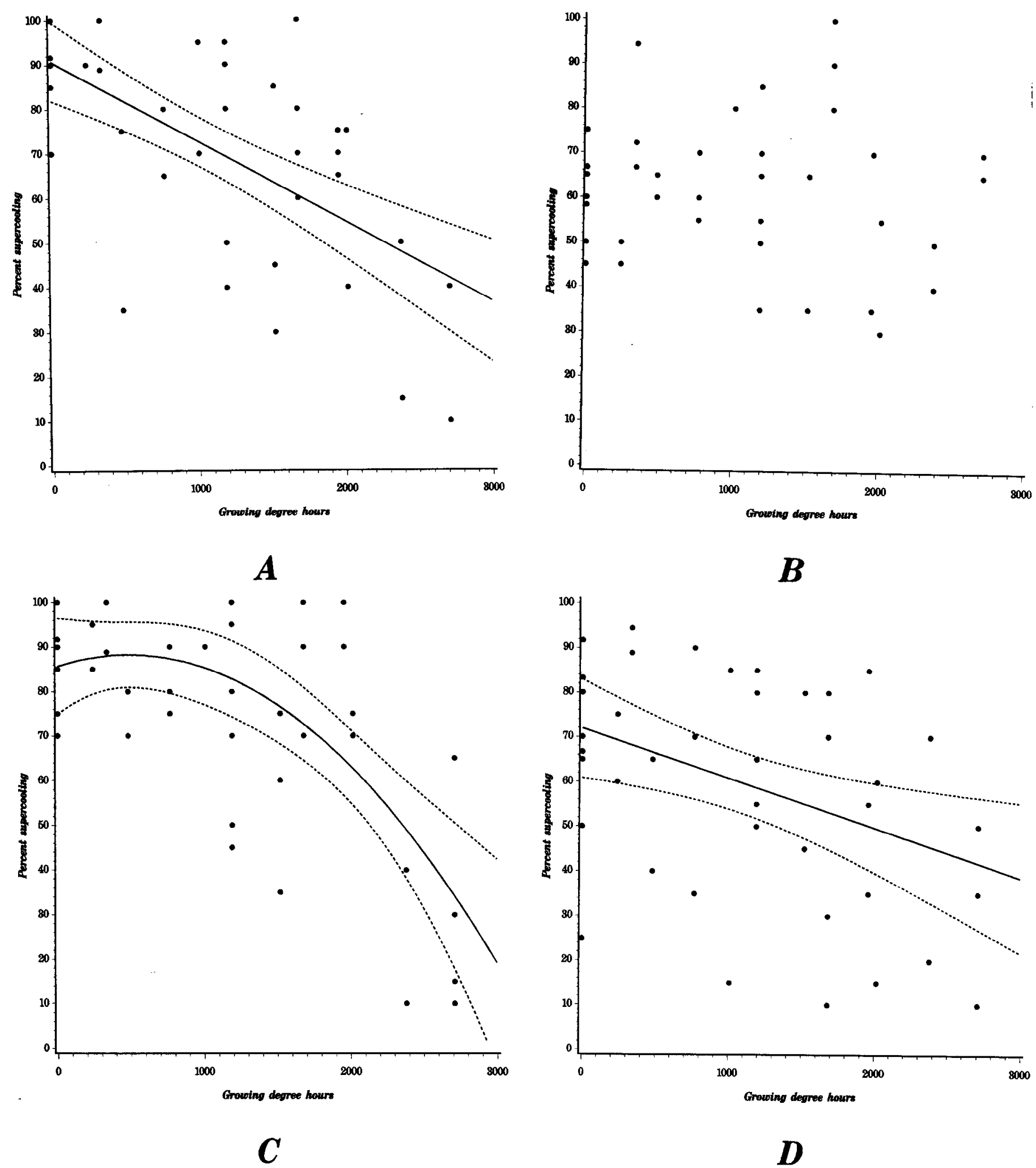

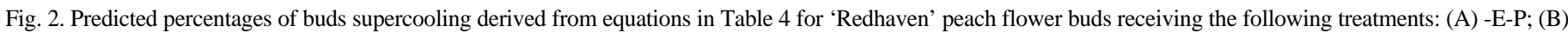
$+E-P,(C)-E+P$, and (D) + E+P. Dashed line indicates $95 \%$ confidence interval for a predicted mean value. Lack of a line indicates no significant relationship detected.

The percentage of buds supercooling from $+\mathrm{E}$ trees did not change with deacclimation or reacclimation treatments. In $-\mathrm{E}$ trees, the percentage of buds supercooling from $-\mathrm{P}$ trees increased with reacclimation. In $+\mathrm{P}$ trees, the percentage of buds supercooling increased with deacclimation, then decreased to predeacclimation levels with reacclimation (Table 4).
Experiment 5. Buds from $+\mathrm{E}$ trees were hardier than $-\mathrm{E}$ buds before deacclimation (MLTEs of -18.4 and $-17.1 \mathrm{C}$, respectively), after deacclimation (MLTEs of -13.9 and $-10.9 \mathrm{C}$, respectively), and after reacclimation (MLTEs of -14.9 and $-10.2 \mathrm{C}$, respectively). Buds from $+\mathrm{P}$ trees were less hardy after deacclimation than those from $-\mathrm{P}$ trees (MLTEs of -11.1 and $-13.8 \mathrm{C}$, respectively). 
Table 4. Mean low-temperature exotherm (MLTE) values and percentages buds supercooling (\%SC) for 'Redhaven' flowerbuds as affected by October ethephon treatment, December pruning, deacclimation at $21 \mathrm{C}$, and reacclimation at $-1 \mathrm{C}$ under controlled conditions with significance probabilities for planned comparisons. Data are from Expt. 4.

\begin{tabular}{|c|c|c|c|c|c|c|c|c|}
\hline \multirow{5}{*}{$\begin{array}{l}\text { Deacclimation } \\
\text { treatment }\end{array}$} & \multicolumn{8}{|c|}{ Ethephon } \\
\hline & \multicolumn{4}{|c|}{-} & \multicolumn{4}{|c|}{+} \\
\hline & \multicolumn{8}{|c|}{ Pruning } \\
\hline & \multicolumn{2}{|c|}{-} & \multicolumn{2}{|c|}{+} & \multicolumn{2}{|c|}{-} & \multicolumn{2}{|c|}{+} \\
\hline & MLTE & $\% \mathrm{SC}$ & MLTE & $\% \mathrm{SC}$ & MLTE & $\% \mathrm{SC}$ & MLTE & $\% \mathrm{SC}$ \\
\hline No deacclimation & -17.8 & 77 & -17.6 & 82 & -18.9 & 62 & -17.8 & 65 \\
\hline 2 days at $21 \mathrm{C}$ & -5.7 & 73 & -14.9 & 96 & -16.2 & 58 & -17.8 & 58 \\
\hline 2 days at $21 C+1$ day at $-1 C$ & -18.2 & 92 & -17.4 & 75 & -19.5 & 50 & -19.0 & 77 \\
\hline \multicolumn{9}{|c|}{ Comparison significance prohabilities ${ }^{z}$} \\
\hline $\begin{array}{l}\text { (No deacclimation) vs. } \\
(2 \text { days at } 21 \mathrm{C}) \\
(2 \text { days at } 21 \mathrm{C}) \text { vs. }\end{array}$ & 0.01 & NS & 0.01 & 0.03 & 0.01 & NS & NS & NS \\
\hline $\begin{array}{l}\text { ( } 2 \text { days at } 21 \mathrm{C}+1 \text { day at }-1 \mathrm{C}) \\
\text { (No deacclimation) vs. }\end{array}$ & 0.01 & 0.03 & 0.01 & 0.01 & 0.01 & NS & 0.01 & NS \\
\hline (2 days at $21 C+1$ day at $-1 C)$ & NS & NS & NS & NS & NS & NS & 0.01 & NS \\
\hline
\end{tabular}

${ }^{\overline{2}}$ Comparisons made within column.

${ }^{\mathrm{Ns}}$ Nonsignificant at $\mathrm{a}=0.05$.

Buds from all treatments lost hardiness when exposed to the deacclimation treatments. However, buds from $+\mathrm{E}+\mathrm{P}$ trees rehardened when given the reacclimation treatment (Table 5). Buds from $+\mathrm{E}+\mathrm{P}$ trees dehardened much more than those from $+\mathrm{E}$ $\mathrm{P}$ trees during the deacclimation treatment, thus the rehardening at $-1 \mathrm{C}$ was such that it brought the bud hardiness level of $+\mathrm{P}$ trees to that of $-\mathrm{P}$ trees. Buds from $-\mathrm{E}+\mathrm{P}$ trees continued to deharden and no exotherms were detected after rehardening. Few exotherms were detected after rehardening for buds from -E-P trees as well. The MLTEs of buds from $+E$ trees were lower than those for buds from $-\mathrm{E}$ trees, and significantly more $+\mathrm{E}$ buds supercooled after reacclimation at $-1 \mathrm{C}$. Buds from $-\mathrm{E}$ trees continued to deharden while those from $+\mathrm{E}$ trees did not during the reacclimation treatment.

\section{Pistil size and moisture content}

Experiments 1 and 3. Pistils from $+\mathrm{E}$ buds were significantly shorter than those from-E buds (mean lengths 0.88 and $1.16 \mathrm{~mm}$, respectively), pistils from $+\mathrm{P}$ trees were significantly longer than those from-P trees (mean lengths 1.05 and $0.99 \mathrm{~mm}$, respectively), and deacclimated pistils were significantly longer than nondeacclimated pistils (mean lengths 1.07 and $0.97 \mathrm{~mm}$, respectively).

Experiments 2 and 3. Pistils from $+\mathrm{E}$ buds had a significantly lower mean moisture content $(67.4 \%)$ than those from -E buds (70.6\%). Pistil moisture increased significantly from $67.0 \%$ before deacclimation to $71.0 \%$ after deacclimation. Pistils from $+\mathrm{E}$ buds were significantly lighter than those from -E buds (mean fresh weights of 1.2 and $2.3 \mathrm{mg}$, respectively) and deacclimated pistils were significantly heavier than nondeacclimated pistils (mean fresh weights of 1.9 and $1.6 \mathrm{mg}$, respectively).

Experiment 5 . Pistils from $+\mathrm{E}$ buds were significantly shorter and lighter $(1.56 \mathrm{~mm}, 4.2 \mathrm{mg})$ than those from -E buds $(2.68 \mathrm{~mm}$, $5.3 \mathrm{mg}$ ). Pistils from-P trees were significantly shorter than pistils from $+\mathrm{P}$ trees $(2.03 \mathrm{~mm}$, and $2.27 \mathrm{~mm}$, respectively). Fresh weight decreased significantly from $5.8 \mathrm{mg} /$ pistil before dehardening to $4.3 \mathrm{mg} /$ pistil after deacclimation. There was no effect of deacclimation on moisture content; thus, the decrease in fresh weight could be due to depletion of stored food reserves. Moisture of pistils from-P trees was significantly greater $(83.9 \%)$ than that of pistils from $+\mathrm{P}$ trees $(71.1 \%)$.

\section{Discussion}

In the field, $+\mathrm{E}$ buds were as hardy or hardier than $-\mathrm{E}$ buds on 10 of 11 dates. On the earliest date, $+\mathrm{E}$ buds were less hardy than -E buds. An effect of pruning on hardiness was not always detected; however, when it was, pruning reduced bud hardiness. Field temperatures of $15.5 \mathrm{C}$ on $16 \mathrm{Jan}$. and $19.0 \mathrm{C}$ on $17 \mathrm{Jan}$. (before sampling) induced dehardening in-E trees. Buds from $+\mathrm{E}$ trees did not deharden. Buds from $+\mathrm{P}$ trees were less hardy than those from-P trees. Rehardening occurred by the 19 Jan. sampling date (Table 1) in all dehardened buds due to a field temperature of $-2 \mathrm{C}$ before sampling. Buds from $+\mathrm{P}$ trees did not reharden as much as those from-P trees (Table 1). These results indicate that pruning intensifies dehardening during exposure to warm temperatures and also confirms that dormant pruning reduces the capacity to reharden after a thaw (Durner, 1990). Durner (1990) reported that trees pruned after their chilling requirement had been fulfilled did not reharden. Trees pruned before the end of endodormancy rehardened. In this study, trees were pruned before completion of endodormancy (525 CUs) and they rehardened after a warm spell; however, they did not reharden as much as nonpruned trees. The sensitivity to pruning likely increases gradually as CUs accumulate, much like flower bud growth response to heat and CUs (Durner and Gianfagna, 1991a). Buds from $+\mathrm{E}+\mathrm{P}$ trees did not deharden with a 2-day thaw (522 GDH). Dumer (1990) reported that buds from $+\mathrm{E}+\mathrm{P}$ trees dehardened during a 5-day thaw (479 $\mathrm{GDH})$. The difference between the two studies is likely related to the dehardening regime each study incurred. In the first report, buds were exposed to $136 \mathrm{~h}$ above freezing (Durner, 1990). In this study, buds were exposed to $40 \mathrm{~h}$ above freezing. Even though the total GDH accumulated during the two thaws was similar, the rates of heat accumulation were not. Since $+E$ buds deharden slowly (Durner and Gianfagna, $1991 \mathrm{a}$ ), a long slow thaw is likely to cause more dehardening than a short, intense thaw. Perhaps $+E$ buds deharden at a rate that is not affected by the intensity of heat as much as by the duration of heat. The controlled dehardening showed that buds from $+\mathrm{E}+\mathrm{P}$ trees deharden, but not as fast as $\mathrm{E}+\mathrm{P}$ trees (Fig. 1D vs. C).

The response surface analysis of the controlled deacclimation experiments confirm the field observations regarding the effects of 
Table 5. Mean low-temperature exotherm (MLTE) values and percentages buds supercooling (\%SC) for 'Redhaven' flower buds as affected by October ethephon treatment, December pruning, deacclimation at $21 \mathrm{C}$, and reacclimation at $-1 \mathrm{C}$ under controlled conditions with significance probabilities for planned comparisons. Data are from Expt. 5.

\begin{tabular}{|c|c|c|c|c|c|c|c|c|}
\hline \multirow{5}{*}{$\begin{array}{l}\text { Deacclimation } \\
\text { treatment }\end{array}$} & \multicolumn{8}{|c|}{ Ethephon } \\
\hline & \multicolumn{4}{|c|}{-} & \multicolumn{4}{|c|}{+} \\
\hline & \multicolumn{8}{|c|}{ Pruning } \\
\hline & \multicolumn{2}{|c|}{-} & \multicolumn{2}{|c|}{+} & \multicolumn{2}{|c|}{-} & \multicolumn{2}{|c|}{+} \\
\hline & MLTE & $\% \mathrm{SC}$ & MLTE & $\% S C$ & MLTE & $\% \mathrm{SC}$ & MLTE & $\% \mathrm{SC}$ \\
\hline No deacclimation & -17.0 & 68 & -17.2 & 68 & -18.2 & 67 & -18.5 & 83 \\
\hline 2 days at $21 \mathrm{C}$ & -11.5 & 30 & -10.3 & 40 & -15.2 & 45 & -11.9 & 32 \\
\hline 2 days at $21 C+1$ day at $-1 C$ & -10.2 & 5 & --- & 0 & -15.2 & 26 & -14.5 & 16 \\
\hline \multicolumn{9}{|c|}{ Comparison significance probabilities ${ }^{y}$} \\
\hline $\begin{array}{l}\text { (No deacclimation) vs. } \\
\text { ( } 2 \text { days at } 21 \mathrm{C})\end{array}$ & 0.01 & NS & 0.01 & 0.04 & 0.01 & NS & 0.01 & 0.01 \\
\hline $\begin{array}{l}\text { ( } 2 \text { days at } 21 \mathrm{C}) \text { vs. } \\
(2 \text { days at } 21 \mathrm{C}+1 \text { day at }-1 \mathrm{C}) \\
\text { (No deacclimation) vs. }\end{array}$ & NS & NS & --- & 0.01 & NS & NS & 0.01 & NS \\
\hline ( 2 days at $21 C+1$ day at $-1 C)$ & 0.01 & 0.01 & --- & 0.01 & 0.01 & NS & 0.01 & 0.01 \\
\hline
\end{tabular}

${ }^{2}$ No low temperature exotherms detected for this sample.

${ }^{y}$ Comparisons made within column.

${ }^{\mathrm{Ns}}$ Nonsignificant at $\alpha=0.05$.

pruning and ethephon on the rate and extent of dehardening. Buds from $-\mathrm{E}$ trees deharden more rapidly and to a greater extent than those from $+E$ trees. Pruning accelerates and intensifies dehardening. Treatment with ethephon before pruning reduces but does not negate the intensified dehardening effect of pruning.

In the planned comparison analysis, ethephon increased bud hardiness by decreasing the LTE and by reducing dehardening at warm temperatures as previously reported (Durner and Gianfagna, 199 la). Pruning reduced bud hardiness by stimulating pistil growth Pistils from $+\mathrm{P}$ trees were longer than those from $-\mathrm{P}$ trees (Expts 1, 3, and 5), and pruning accelerated bloom by 3 days. Fall ethephon reduces pistil growth rate (Durner and Gianfagna, 1991a, $1991 \mathrm{~b}$ ); thus, the reduced response to pruning observed in $+\mathrm{E}$ trees was likely due to reduced pistil growth compared to $-\mathrm{E}$ trees.

Pistil water content is an important factor in supercooling. Quamme and Gusta (1987) proposed that peach flower primordia have an intrinsic resistance to ice nucleation that may be due to lower water and osmotic potentials in pistils compared to the surrounding tissue in the bud. This difference in osmotic potentials may lead to the formation of discontinuities between the liquid phase in the pistil and the ice in surrounding tissues (Quamme and Gusta, 1987) . Discontinuities could prevent nucleation of pistil water by ice from bud scales or vascular traces (Cary, 1985) and allow deep supercooling. Lower pistil moisture might enhance supercooling (Quamme, 1983). Increased pistil moisture is often concomitant with a decrease in hardiness (Expts. 2 and 3; Durner and Gianfagna, $1991 \mathrm{~b}$ ); however, a change in pistil moisture is not a prerequisite for a change in hardiness. Quamme (1983) and Durner and Gianfagna (1989) have observed differences in pistil hardiness not associated with differences in pistil moisture. These studies support that view. With forced deacclimation, buds dehardened, but there was no effect of deacclimation on pistil moisture (Expt. 5). Additionally, reduced pistil moisture does not necessarily lead to increased hardiness. Moisture content of pistils from -P trees was greater than that of pistils from $+\mathrm{P}$ trees, yet pistils from- $\mathrm{P}$ trees were hardier than those from $+\mathrm{P}$ trees (Expt. 5).

In summary, dormant pruning reduces peach flower bud hardiness by stimulating bud development. Increased bud development leads to increased dehardening during warm weather and reduced rehardening during cold weather. A fall application of ethephon reduces, but does not negate, the detrimental impact of dormant pruning on bud hardiness.

\section{Literature Cited}

Andrews, P.K., E.L. Proebsting, and D.C. Gross. 1983. Differential thermal analysis and freezing injury of deacclimating peach and sweet cherry reproductive organs. J. Amer. Soc. Hort. Sci. 108:755-759.

Ca.ry, J.W. 1985. Freeze survival in peach and prune flowers. Plant Sci. Let. 37:265-271.

Durner, E.F. 1989. Cryoprotection of deacclimating peach flower buds by ethephon alteration of pistil carbohydrate content. Cryobiology 26:290-296.

Durner, E.F. 1990. Dormant pruning reduces rehardening of peach pistils after a winter thaw. HortScience 25:980.

Durner, E.F. and T.J. Gianfagna. 1988. Fall ethephon application increases peach flower bud resistance to low-temperature stress. J. Amer. Soc. Hort. Sci. 113:404406.

Durner, E.F. and T.J. Gianfagna. 1989. Ethephon alters dormant peach flower bud carbohydrate and water content. Acta Hort. 254:297-302.

Durner, E.F. and T.J. Gianfagna. 1990. Peach pistil growth inhibition and subsequent bloom delay by midwinter bud whitewashing. HortScience 25: 1222-1224.

Durner, E.F. and T.J. Gianfagna. 1991a. Ethephon prolongs dormancy and enhances supercooling in peach flower buds. J. Amer. Soc. Hort. Sci. 116:500-506.

Durner, E.F. and T.J. Gianfagna. 1991b. Peach pistil carbohydrate and moisture contents and growth during controlled deacclimation following ethephon application. J. Amer. Soc. Hort. Sci. 116:507-511.

Gianfagna, T.J., E.F. Dumer, and G.S. Teiger. 1989. Reducing low temperature injury to peach flower buds with ethephon. Acta Hort. 239:203-206.

Irving, D.E. 1987. 'Fantasia' nectarine: Effects of autumn-applied ethephon on blossoming and cropping. New Zealand J. Expt. Agr. 15:67-72.

Proebsting, Jr., E.L. and H.H. Mills. 1969. Effects of growth regulators on fruit bud hardiness in Prunus. HortScience 4:254-255.

Proebsting, Jr., E.L. and H.H. Mills. 1976. Ethephon increases cold hardiness of sweet cherry. J. Amer. Soc. Hort. Sci. 101:31-33.

Quamme, H.A. 1978. Mechanism of supercooling in overwintering peach flower buds. J. Amer. Soc. Hort. Sci. 103:57-61.

Quamme, H.A. 1983. Relationship of air temperature to water content and supercooling of overwintering peach flower buds. J. Amer. Soc. Hort. Sci. 108:697701.

Quamme, H.A. and L.V. Gusta. 1987. Relationship of ice nucleation and water status to freezing patterns in dormant peach flower buds. HortScience 22:465467.

Richardson, E.A., S.D. Seeley, and D.R. Walker. 1974. A model for estimating the completion of rest for 'Redhaven' and 'Elberta' peach trees. HortScience 9:331332.

SAS Institute. 1985. SAS/STAT guide for personal computers. version 6. SAS Inst., Gary, N.C.

Weisberg, S. 1985. Applied linear regression. Wiley, New York. 